Jurnal Ilmu Ilmu Agribisnis: Journal of Agribusiness Science, 9(1), Februari 2021

\title{
ANALISIS HARGA POKOK PENJUALAN DAN FAKTOR-FAKTOR YANG MEMPENGARUHI PRODUKSI USAHATANI UBI KAYU DI KABUPATEN LAMPUNG TENGAH
}

\author{
(Analysis of the Selling Standard Cost and Factors Affecting Cassava Production \\ in Central Lampung District)
}

Rohayani, R Hanung Ismono, Rabiatul Adawiyah

\begin{abstract}
Jurusan Agribisnis, Fakultas Pertanian, Universitas Lampung, Jl. Prof. Dr. Soemantri Brodjonegoro No. 1 Bandar Lampung 35145, e-mail: hanung.ismono@fp.unila.ac.id
\end{abstract}

\begin{abstract}
The objectives of this research are to find out the selling standard cost of cassava production and the factors that influence the production of cassava farming. The research was a survey conducted in Central Lampung Regency in October-November 2018. The samples are 73 cassava farmers selected randomly. Data were analyzed using total income, total costs, profit margin, and Cobb-Douglas production function. The results showed that selling standard cost with profit margin of 13 percent is IDR1,145.81 in Terusan Nunyai Subsdistrict and IDR1,032.59 in Bandar Mataram Subsdistrict. The average price received by farmers is IDR1,456.57 and IDR1,570.65 respectively. It means that farmers have benefit from technical efficiency of cassava farming. There is a significant difference between the selling cost of cassava in area close to factory and that in farther area. The factors that affect the production of cassava are seeds, urea fertilizer, and location.
\end{abstract}

Keywords: Cassava, determining production cost, determining selling cost, farming.

\section{PENDAHULUAN}

Salah satu pendorong perekonomian Indonesia berasal dari bidang pertanian, hal ini karena sektor pertanian hingga saat ini memiliki peranan yang sangat penting. Pembangungan sektor pertanian khususnya subsektor tanaman pangan diarahkan untuk meningkatkan produksi, sehingga tercipta swasembada pangan yang dapat meningkatkan pendapatan petani. Salah satu jenis tanaman pangan yang sudah lama dibudidayakan oleh petani di seluruh wilayah nusantara adalah ubi kayu. Peran ubi kayu selama ini tidak mampu mengangkat ekonomi masyarakat dan masyarakat tidak mengetahui pemanfaatan ubi kayu yang digunakan sebagai bahan baku industri, sehingga perkembangan ubi kayu di area petani relatif tidak mengalami pertumbuhan yang berarti.

Produksi ubi kayu terbesar di Kabupaten Lampung Tengah yaitu dari Kecamatan Bandar Mataram dengan produksi mencapai 222.976 ton dan Kecamatan Terusan Nunyai dengan produksi sebesar 143.338 ton (BPS 2016). Sebagai sentra ubi kayu di Kabupaten Lampung Tengah, beberapa kecamatan mempunyai pabrik untuk mengolah hasil panen ubi kayu. Terdapat pabrik yang lokasinya dekat dengan usahatani ubi kayu yaitu Kecamatan Terusan Nunyai, sehingga biaya transportasi yang dikeluarkan petani minimal dan keuntungan yang diperoleh maksimal. Hal ini berbeda dengan Kecamatan Bandar Mataram dimana lokasi usahatani jauh dari pabrik, sehingga biaya transportasi yang dikeluarkan lebih banyak dan keuntungan yang didapat lebih minimal. Keuntungan yang diterima petani ditentukan atas harga hasil produksi (output) dan harga faktor produksi yang diterima (input). Petani ubi kayu sebagai produsen yang memproduksi ubi kayu berorientasi pada laba, serta biaya yang telah dikeluarkan sebagai elemen perhitungan dalam pembentukan harga pokok produksi. Harga pokok produksi sangat berpengaruh dalam perhitungan laba rugi. Harga pokok produksi usahatani ubi kayu merupakan total biaya yang dikeluarkan oleh petani ubi kayu dalam suatu proses budidaya pada satu musim tanam. Petani akan menanggung biaya produksi dalam melakukan kegiatan budidaya ubi kayu.

Berdasarkan harga pokok produksi akan diperoleh harga pokok penjualan. Penetapan harga pokok penjualan ubi kayu menjadi sangat penting bagi petani, karena merupakan salah satu penentu keberhasilan suatu usaha yang akan menentukan seberapa besar keuntungan yang diperoleh petani atas penjualan produknya. Harga ubi kayu yang ditawarkan oleh pabrik masih dinilai terlalu rendah dan tidak kompetitif dengan nilai ekonomi komoditas lain. Rata-rata harga ubi kayu tahun 2015 Rp1.068 dan mengalami penurunan pada tahun 2016 menjadi Rp622 dan pada tahun 2017 mengalami peningkatan menjadi Rp757 (BPS Provinsi Lampung 2017). Harga ubi kayu belum 
mampu menjadi insentif bagi petani untuk meningkatkan produksinya dan penurunan harga ubi kayu dapat menyebabkan usahatani ubi kayu tidak efisien.

Pengalaman petani menunjukkan bahwa penanaman ubi kayu sering tidak membuahkan hasil yang cukup baik, karena keadaan tataniaga ubi kayu yang banyak dipengaruhi oleh fluktuasi harga sehingga merugikan petani. Kegiatan usahatani yang dilakukan tidak hanya meningkatkan produksi, tetapi juga meningkatkan pendapatan melalui pemanfaatan penggunaan faktor produksi. Penggunaan faktor produksi yang tidak efisien dalam usahatani ubi kayu akan mengakibatkan rendahnya produksi dan tingginya biaya yang pada akhirnya mengurangi pendapatan petani. Berdasarkan uraian latar belakang, maka penelitian ini bertujuan untuk menganalisis perbedaan harga pokok penjualan ubi kayu berdasarkan lokasi pabrik dan faktor-faktor yang mempengaruhi produksi usahatani ubi kayu di Kabupaten Lampung Tengah.

\section{METODE PENELITIAN}

Penelitian dilakukan di Kecamatan Terusan Nunyai dan Kecamatan Bandar Mataram Kabupaten Lampung Tengah dengan menggunakan metode penelitian survei. Pengambilan data dilakukan di empat desa yaitu Desa Gunung Agung dan Gunung Batin Udik di Kecamatan Terusan Nunyai dan Desa Mataram Udik dan Mataram Jaya di Kecamatan Bandar Mataram, dengan pertimbangan bahwa keempat desa tersebut merupakan sentra ubi kayu di Kabupaten Lampung Tengah. Data yang digunakan adalah data primer dan data sekunder. Pengumpulan data dilaksanakan sejak bulan Oktober - November 2018. Populasi pada penelitian ini adalah petani ubi kayu. Berdasarkan UPTD Pertanian di lokasi penelitian, jumlah petani ubi kayu sebanyak 2.280 dan dari populasi tersebut ditentukan jumlah sampel penelitian yang mengacu pada Issac dan Michael dalam Sugiarto et al. (2003) sebagai berikut :

$\mathrm{n}=\frac{\mathrm{N} \mathrm{Z} \mathrm{S}^{2}}{\mathrm{~N} \mathrm{~d}^{2}+\mathrm{Z}^{2} \mathrm{~S}^{2}}$

Keterangan:

$\mathrm{n} \quad=$ Jumlah sampel

$\mathrm{N} \quad=$ Jumlah populasi

$\mathrm{S}^{2} \quad=$ Variasi sampel $(5$ persen $=0,05)$

$\mathrm{Z} \quad=$ Tingkat kepercayaan $(95$ persen $=1,96)$

$\mathrm{d}=$ Derajat penyimpangan $(5$ persen $=0,05)$
Berdasarkan rumus pada persamaan (1), jumlah sampel yang diperoleh adalah 73 orang, selanjutnya dihitung alokasi secara proposional dengan rumus Sugiyono (2007) yaitu :

$\mathrm{n}_{\mathrm{a}}=\frac{\mathrm{N}_{\mathrm{a}}}{\mathrm{N}_{\mathrm{ab}}} \cdot \mathrm{n}_{\mathrm{ab}}$

Keterangan :

$\mathrm{n}_{\mathrm{a}} \quad=$ Jumlah sampel desa $\mathrm{A}$

$\mathrm{n}_{\mathrm{ab}} \quad=$ Jumlah sampel keseluruhan

$\mathrm{N}_{\mathrm{a}} \quad$ Jumlah populasi desa A

$\mathrm{N}_{\mathrm{ab}} \quad=$ Jumlah populasi keseluruhan

Berdasarkan perhitungan diperoleh jumlah sampel di Kecamatan Terusan Nunyai sebanyak 42 orang dan di Kecamatan Bandar Mataram sebanyak 21 orang. Pengambilan sampel dilakukan secara acak sederhana.

Metode analisis perbedaan harga pokok penjualan ubi kayu dilakukan menggunakan uji Independent Samples Test. Perhitungan harga pokok penjualan dilakukan melalui dua tahap yaitu pertama menghitung harga pokok produksi, kedua menghitung harga pokok penjualan. Pada penelitian ini, perhitungan harga pokok produksi ditunjukkan pada tabel 1.

Tabel 1. Perhitungan harga pokok produksi usahatani ubi kayu

\begin{tabular}{|c|c|}
\hline \multirow{2}{*}{\multicolumn{2}{|c|}{ Penerimaan }} \\
\hline & \\
\hline Produksi & A \\
\hline Biaya Produksi & \\
\hline I.Biaya Bahan Baku & B \\
\hline Bibit & \\
\hline Pupuk & \\
\hline Herbisida & \\
\hline II.Biaya Tenaga Kerja & $\mathrm{C}$ \\
\hline TK Luar Keluarga & \\
\hline TK Dalam Keluarga & \\
\hline III.Biaya Overhead & $\mathrm{D}$ \\
\hline Penyusutan Alat & \\
\hline Sewa Lahan & \\
\hline Pajak & \\
\hline Biaya Angkut & $\mathrm{E}$ \\
\hline Potongan Pabrik & $\mathrm{F}$ \\
\hline Total Biaya Variabel & $\mathrm{G}=\mathrm{B}+\mathrm{C}+\mathrm{E}+\mathrm{F}$ \\
\hline Total Biaya Tetap & $\mathrm{H}=\mathrm{D}$ \\
\hline Total Biaya & $\mathrm{I}=\mathrm{G}+\mathrm{H}$ \\
\hline Harga Pokok Produksi & \\
\hline Metode Variable Costing & $\mathrm{J}=\mathrm{G} / \mathrm{A}$ \\
\hline Metode Full Costing & $=\mathrm{I} / \mathrm{A}$ \\
\hline
\end{tabular}

Sumber : Mulyadi (2001) 
Penentuan harga pokok produksi menggunakan dua metode pendekatan, yaitu pendekatan full costing dan variabel costing. Perhitungan harga pokok produksi pada usahatani ubi kayu menggunakan metode full-costing. Metode fullcosting adalah metode penentuan harga pokok produksi yang memperhitungkan seluruh unsur biaya produksi, terdiri dari bahan baku, biaya tenaga kerja, dan biaya tidak langsung tetap maupun variabel. Unsur-unsur harga pokok produksi digolongkan menjadi tiga yaitu biaya bahan baku (saprodi), biaya tenaga kerja, dan biaya overhead. Saprodi meliputi bibit, pupuk, dan herbisida. Biaya tenaga kerja merupakan total upah tenaga kerja yang dikeluarkan petani dalam proses usahatani mulai dari persiapan lahan sampai panen. Biaya overhead usahatani ubi kayu meliputi penyusutan alat, biaya sewa lahan, dan biaya pajak tanah. Perhitungan harga pokok penjualan menggunakan metode menurut Kuotsoyiannis (1982), dengan aturan mark up sebagai berikut:

Harga Pokok Penjualan = HPProd +13 Persen...(3)

Margin keuntungan dihitung berdasarkan tingkat suku bunga tahun 2017 yaitu 9 persen (BRI 2017) dan tingkat inflasi 3,61 persen (BPS Provinsi Lampung 2017). Margin keuntungan digunakan untuk menunjukkan besarnya keuntungan yang diperoleh petani atas penjualan hasil produksinya, sehingga diperoleh margin keuntungan yang akan digunakan dalam penelitian ini adalah sebesar 13 persen.

Analisis fungsi Cobb-Douglas digunakan untuk mengetahui pengaruh penggunaan faktor-faktor produksi ubi kayu yang dihasilkan. Secara sistematis, model fungsi produksi Cobb-Douglas yang digunakan dalam penelitian ini adalah (Soekartawi 2003) :

$\mathrm{Y}=\mathrm{bo} \mathrm{X}_{1}{ }^{\mathrm{b} 1} \mathrm{X}_{2}{ }^{\mathrm{b} 2} \mathrm{X}_{3}{ }^{\mathrm{b} 3} \mathrm{X}_{4}{ }^{\mathrm{b} 4} \mathrm{X}_{5}^{\mathrm{b} 5} \mathrm{X}_{6}{ }^{\mathrm{b} 6} \mathrm{X}_{7}{ }^{\mathrm{b} 7} \mathrm{X}_{8}{ }^{\mathrm{b} 8} \mathrm{X}_{9}{ }^{\mathrm{b} 9} \mathrm{e}^{\mathrm{d} 1 \mathrm{D} 1}(4)$

Persamaan fungsi produksi Cobb-Douglas diubah menjadi bentuk linier dengan cara melogaritmakan persamaan tersebut (Soekartawi 2003) yaitu:

$\operatorname{LnY}=\operatorname{Lnb}_{o}+b_{1} \operatorname{Ln} X_{1}+\ldots+b_{9} \operatorname{Ln} X_{9}+d_{1} D_{1}+u \ldots .(5)$

Keterangan :

$\mathrm{b}_{\mathrm{o}} \quad=$ Intersep

b1 = Koefisien regresi penduga variabel ke-i

$\mathrm{Y}=$ Produksi $(\mathrm{kg})$

$\mathrm{X}_{1} \quad=$ Luas lahan (ha)

$\mathrm{X}_{2} \quad=$ Bibit (batang)

$\mathrm{X}_{3} \quad=$ Pupuk urea $(\mathrm{kg})$

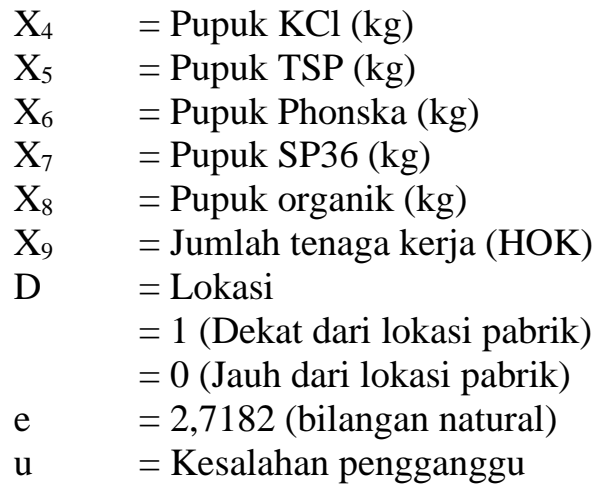

Uji $F$ digunakan untuk mengetahui pengaruh faktor-faktor produksi secara serempak terhadap hasil produksi ubi kayu. Uji-t digunakan untuk mengetahui pengaruh faktor produksi secara tunggal dalam pengujian regresi terhadap produksi ubi kayu. Uji asumsi klasik digunakan untuk mengetahui ada tidaknya gejala multikolineritas dan heterokedastisitas. Jika nilai VIF lebih besar dari 10 menyatakan bahwa terdapat multikolineritas antar variabel independen (Suliyanto 2011). Pengujian heterokedastisitas digunakan dengan $U j i$ White, apabila nilai prob $o b s * R$ squared $\leq 0,05$, hal tersebut menunjukan bahwa terdapat masalah heterokedastisitas (Gujarati 2003).

\section{HASIL DAN PEMBAHASAN}

Sebesar 53,42 persen petani berada pada kelompok umur 39-59 tahun dan 60,27 persen petani pernah menempuh pendidikan formal pada tingkat sekolah dasar (SD). Pengalaman petani dalam berusahatani ubi kayu cukup beragam, yaitu pengalaman paling rendah adalah 5 tahun dan tertinggi adalah 41 tahun. Sebesar 83,56 persen petani ubi kayu memiliki jumlah tanggungan keluarga antara 3-5 jiwa. Luas lahan tersempit petani ubi kayu adalah 1 ha dan luas lahan terbesar adalah 8 ha, dengan status kepemilikan lahan sebanyak 94,52 persen milik sendiri dan 5,48 persen status lahan sewa. Pendapatan petani di luar kegiatan usahatani diperoleh dari pekerjaan sampingan yang berasal sektor on farm yaitu peternak, off farm yaitu kios tani dan buruh tani, sedangkan sektor non farm yaitu buruh pabrik, wiraswasta, dan pedagang (warung).

Bibit yang digunakan petani pada usahatani ubi kayu di Kecamatan Terusan Nunyai adalah Thailand dan di Kecamatan Bandar Mataram adalah Casessart. Batang ubi kayu biasanya dijual per ikat, terdiri dari 50 batang. Pupuk yang banyak digunakan oleh petani di Kecamatan Terusan Nunyai adalah pupuk $\mathrm{KCl}$ dengan harga 
Rp4.541,03 per liter, sedangkan pupuk yang banyak digunakan di Kecamatan Bandar Mataram yaitu pupuk phonska dengan harga Rp2.914,81 per liter. Herbisida yang paling banyak digunakan di dua lokasi penelitian adalah gramoxone dan alat yang paling banyak digunakan dalam usahatani ubi kayu adalah cangkul, arit, sprayer dan golok. Penggunaan tenaga kerja terdiri dari tenaga kerja dalam keluarga dan tenaga kerja luar keluarga, baik pria maupun wanita yang dikonversikan ke dalam Hari Orang Kerja (HOK) berdasarkan 8 standar jam kerja dan upah sesuai dengan upah yang berlaku di daerah penelitian. Rata-rata pengunaan tenaga kerja dalam usahatani ubi kayu berasal dari tenaga kerja luar keluarga dan pengunaan tenaga kerja terbanyak adalah pada kegiatan pemanenan.

\section{Pendapatan Usahatani Ubi Kayu}

Pendapatan usahatani merupakan pengurangan antara penerimaan dan biaya produksi. Biaya produksi dalam usahatani ubi kayu di daerah penelitian terdiri dari biaya tunai, biaya diperhitungkan dan potongan dari pabrik. Biaya tunai meliputi biaya bibit, biaya pupuk, biaya herbisida, biaya tenaga kerja luar keluarga (TKLK), biaya pajak dan sewa lahan (untuk petani lahan sewa) dan biaya angkut. Biaya diperhitungkan meliputi biaya tenaga kerja dalam keluarga (TKDK), biaya penyusutan alat, dan biaya sewa lahan (untuk lahan milik sendiri). Ratarata luas lahan petani ubi kayu di Kecamatan Terusan Nunyai adalah 2,02 ha dan Kecamatan Bandar Mataram adalah 1,81 ha.

Tabel 2. Rata-rata pendapatan usahatani ubi kayu per hektar di Kecamatan Terusan Nunyai dan Kecamatan Bandar Mataram

\begin{tabular}{|c|c|c|c|c|c|c|c|}
\hline \multirow{2}{*}{ Uraian } & \multirow{2}{*}{ Satuan } & \multicolumn{3}{|c|}{ Terusan Nunyai } & \multicolumn{3}{|c|}{ Bandar Mataram } \\
\hline & & Jumlah & Harga & Nilai & Jumlah & Harga & Nilai \\
\hline \multicolumn{8}{|l|}{$\overline{\text { Penerimaan }}$} \\
\hline Produksi & $\mathrm{Kg}$ & 25.327 & $1.456,67$ & $36.893 .122,35$ & 26.644 & $1.570,65$ & $41.848 .414,12$ \\
\hline \multicolumn{8}{|l|}{ Biaya Produksi } \\
\hline \multicolumn{8}{|l|}{ I. Biaya Tunai } \\
\hline Bibit & Batang & 17783 & 173,81 & $3.090 .806,17$ & 155.566 & 189,68 & $2.952 .490,79$ \\
\hline Pupuk & $\mathrm{Kg}$ & & & & & & \\
\hline P. Urea & $\mathrm{Kg}$ & 148,22 & $2.125,00$ & $314.967,88$ & 131,88 & $1.903,85$ & $251.086,46$ \\
\hline P. $\mathrm{KCl}$ & $\mathrm{Kg}$ & 196,55 & $4.541,03$ & $892.522,43$ & 81,98 & $2.914,81$ & $389.611,68$ \\
\hline P. TSP & $\mathrm{Kg}$ & 130,54 & $4.806,67$ & $627.461,50$ & 44,56 & $2.500,00$ & $84.655,14$ \\
\hline P. Phonska & $\mathrm{Kg}$ & 121,70 & $2.800,00$ & $340.759,08$ & 133,67 & $5.837,50$ & $478.568,88$ \\
\hline P. SP36 & $\mathrm{Kg}$ & & & & 33,86 & 761,11 & $378.453,04$ \\
\hline P. Organik & $\mathrm{Kg}$ & & & & 497,24 & $5.366,67$ & $239.113,65$ \\
\hline \multicolumn{8}{|l|}{ Herbisida } \\
\hline Kleenup & $\mathrm{Lt}$ & & & & 1,41 & $51.964,29$ & $107.429,28$ \\
\hline Gramoxone & $\mathrm{Lt}$ & 1,75 & $61.640,00$ & $107.710,16$ & 2,07 & $63.000,00$ & $53.894,14$ \\
\hline Paratop & $\mathrm{Lt}$ & 0,93 & $62.368,42$ & $57.707,70$ & 0,86 & $50.190,48$ & $57.248,09$ \\
\hline Pilar & $\mathrm{Lt}$ & 0,51 & $62.000,00$ & $31,423,86$ & & & \\
\hline Rambo & $\mathrm{Lt}$ & 0,39 & $53.666,67$ & $21.190,87$ & & & \\
\hline Sidastar & $\mathrm{Lt}$ & 0,31 & $61.666,67$ & $19.261,75$ & & & \\
\hline Glifomin & $\mathrm{Lt}$ & 0,29 & $47.285,71$ & $13.655,12$ & & & \\
\hline TK Luar Keluarga & $\mathrm{Rp}$ & & & $4.353 .253,18$ & & & $4.698 .627,70$ \\
\hline Biaya Angkut & $\mathrm{Rp}$ & & & $825.819,19$ & & & $1.647 .210,84$ \\
\hline Pajak & $\mathrm{Rp}$ & & & $23.279,11$ & & & $27.645,70$ \\
\hline Sewa Lahan & & & & $424.382,15$ & & & \\
\hline Total Biaya Tunai & $\mathrm{Rp}$ & & & $11.144 .146,12$ & & & $11.366 .035,38$ \\
\hline \multicolumn{8}{|l|}{ II.Biaya Diperhitungkan } \\
\hline TK Dalam Keluarga & $\mathrm{Rp}$ & & & $173.208,39$ & & & $226.519,34$ \\
\hline Penyusutan Alat & $\mathrm{Rp}$ & & & $51.613,63$ & & & $51.256,46$ \\
\hline Sewa Lahan & $\mathrm{Rp}$ & & & $5.586 .987,27$ & & & $4.990 .197,83$ \\
\hline Total Biaya & $\mathrm{Rp}$ & & & $5.811 .809,29$ & & & $5.267 .973,62$ \\
\hline \multicolumn{8}{|l|}{ Diperhitungkan } \\
\hline III. Potongan Pabrik 17-21\% & $\mathrm{Rp}$ & & & $8.725 .536,30$ & & & $7.713 .273,93$ \\
\hline IV.Total Biaya & $\mathrm{Rp}$ & & & $25.681 .491,72$ & & & $24.347 .282,93$ \\
\hline \multicolumn{8}{|l|}{ Pendapatan } \\
\hline $\begin{array}{l}\text { I.Pendapatan Atas Biaya } \\
\text { Tunai }\end{array}$ & $\mathrm{Rp}$ & & & 17.023.439,92 & & & $22.769 .104,81$ \\
\hline $\begin{array}{l}\text { II.Pendapatan Atas Biaya } \\
\text { Total }\end{array}$ & $\mathrm{Rp}$ & & & $11.211 .630,63$ & & & $17.501 .131,19$ \\
\hline R/C Atas Biaya Tunai & $\mathrm{Rp}$ & & & 3,31 & & & 3,68 \\
\hline R/C Atas Biaya Total & $\mathrm{Rp}$ & & & 1,44 & & & 1,72 \\
\hline
\end{tabular}


Berdasarkan Tabel 2 dapat diketahui bahwa ratarata hasil produksi ubi kayu di Kecamatan Terusan Nunyai sebanyak $25.327 \mathrm{~kg}$ per hektar dengan harga rata-rata sebesar Rp1.456,67/kg. Rata-rata penerimaan yang diperoleh petani adalah Rp36.893.122,35 dan pendapatan rata-rata atas biaya total sebesar Rp22.647.493,88 atau Rp11.211.630,63 per hektar. Rata-rata hasil produksi di Kecamatan Bandar Mataram sebanyak $26.644 \mathrm{~kg}$ per hektar dengan harga Rp1.570,65/kg. Rata-rata penerimaan yang diperoleh petani adalah Rp41.848.414,12 dan rata-rata pendapatan atas biaya total yang diterima oleh petani adalah Rp31.677.047,46 per 1,81 atau Rp31.677.047,46 per hektar.

Nilai R/C ratio tunai dan total di Kecamatan Terusan Nunyai sebesar 3,31 dan 1,44 artinya setiap Rp1,00 biaya yang dikeluarkan pada usahatani ubi kayu, maka akan mendapatkan penerimaan tunai dan total masing-masing sebesar $\mathrm{Rp} 3,31$ dan $\mathrm{Rp} 1,44$. Nilai $\mathrm{R} / \mathrm{C}$ ratio tunai dan total di Kecamatan Bandar Mataram sebesar 3,68 dan 1,72 artinya setiap $\mathrm{Rp} 1,00$ biaya total yang dikeluarkan akan mendapatkan penerimaan tunai dan total masing-masing Rp3,68 dan Rp1,72. Nisbah penerimaan terhadap biaya tunai dan total yang lebih besar daripada 1 menunjukkan bahwa usahatani ubi kayu yang dilakukan oleh petani tersebut menguntungkan dan layak untuk diusahakan. Perbedaan pendapatan usahatani ubi kayu yang diterima oleh petani di Kecamatan Terusan Nunyai dan di Kecamatan Bandar Mataram, dikarenakan jenis bibit yang digunakan, dan biaya tunai yang dikeluarkan petani yaitu biaya pupuk, biaya herbisida, sewa lahan, pajak dan biaya angkut. Hasil penelitian ini sejalan dengan penelitian Anggraini, Harianto dan Anggraeni (2016) tentang efisiensi teknis dan ekonomi pada usahatani ubi kayu di Kabupaten Lampung Tengah yaitu nilai $\mathrm{R} / \mathrm{C}$ ratio atas biaya tunai dan total sebesar 2,00 dan 1,83 . $\mathrm{R} / \mathrm{C}$ ratio memiliki nilai lebih besar dari satu yang berarti bahwa usahatani ubi kayu layak untuk dilakukan dan menguntungkan.

\section{Harga Pokok Produksi}

Harga pokok produksi merupakan total biaya yang dikeluarkan oleh petani dalam memproduksi atau menghasilkan komoditas per satuan output. Menurut Mulyadi (2007), salah satu manfaat dari penentuan harga pokok produksi yaitu untuk menentukan berapa besarnya harga jual produk. Perhitungan harga pokok produksi ubi kayu dilakukan dengan cara membagi total biaya produksi dengan jumlah produksi. Komponen biaya produksi usahatani ubi kayu meliputi biaya bahan baku (bibit, pupuk, dan herbisida), biaya tenaga kerja, dan biaya overhead usahatani.

Tabel 3 menunjukkan bahwa harga pokok produksi ubi kayu di Kecamatan Terusan Nunyai dengan metode variable costing sebesar Rp790,44/ $\mathrm{kg}$ dan metode full costing sebesar Rp1.013,99/kg nilai tersebut lebih kecil dari harga jual rata-rata ubi kayu yaitu sebesar Rp1.456, 67/kg. Perhitungan harga pokok produksi di Kecamatan Bandar Mataram, dengan metode variable costing sebesar Rp723,54/kg dan metode full costing sebesar Rp913,80/kg yang yang diperoleh dari hasil pembagian total biaya dengan jumlah produksi. Harga pokok produksi yang diperoleh lebih kecil dari harga jual rata-rata ubi kayu yaitu sebesar Rp1,570.65/kg.

Metode full costing yaitu metode yang memperhitungkan semua unsur biaya produksi ke dalam harga pokok produksi meliputi biaya bahan baku, biaya tanaga kerja, dan biaya overhead usahatani, sedangkan metode variable costing merupakan metode penentuan harga pokok produksi yang hanya membebankan biaya-biaya produksi variabel saja. Harga pokok produksi ubi kayu di Kecamatan Terusan Nunyai lebih besar, karena biaya tunai yang dikeluarkan seperti biaya pupuk, biaya pestisida, sewa lahan dan pajak lebih banyak dibandingkan dengan Kecamatan Bandar Mataram, dimana biaya yang lebih besar dikeluarkan adalah biaya angkut, karena lokasi usahatani ubi kayu jauh dari lokasi pabrik tempat penjualan. Oleh sebab itu, dibutuhkan biaya lebih besar pada proses pengangkutan.

Tabel 3. Perhitungan harga pokok produksi ubi kayu di Kabupaten Lampung Tengah

\begin{tabular}{lrr}
\hline \multicolumn{1}{c}{ Uraian } & \multicolumn{1}{c}{$\begin{array}{c}\text { Terusan } \\
\text { Nunyai }\end{array}$} & \multicolumn{1}{c}{$\begin{array}{c}\text { Bandar } \\
\text { Mataram }\end{array}$} \\
\hline Penerimaan & & \\
Produksi & $36.893 .122,35$ & $41.848 .414,12$ \\
I.Biaya Bahan Baku & $5.941 .794,64$ & $4.992 .551,15$ \\
II.Biaya Tenaga Kerja & $4.526 .461,57$ & $4.925 .147,03$ \\
III.Biaya Overhead & $5.661 .880,01$ & $5.069 .099,98$ \\
Biaya Angkut & $825.819,19$ & $1.647 .210,84$ \\
Potongan Pabrik & $8.725 .536,30$ & $7.713 .273,93$ \\
Total Biaya Variabel & $20.019 .611,71$ & $19.278 .182,94$ \\
Total Biaya Tetap & $5.661 .880,01$ & $5.069 .099,98$ \\
Total Biaya & $25.681,491,72$ & $24.347 .282,93$ \\
Harga Pokok Produksi & & \\
Metode Variable Costing & 790,44 & 723,54 \\
Metode Full Costing & $1.013,99$ & 913,80 \\
\hline
\end{tabular}


Tabel 4. Perhitungan harga pokok penjualan ubi kayu di Kabupaten Lampung Tengah

\begin{tabular}{lrr}
\hline \multicolumn{1}{c}{ Uraian } & $\begin{array}{r}\text { Terusan } \\
\text { Nunyai }\end{array}$ & $\begin{array}{c}\text { Bandar } \\
\text { Mataram }\end{array}$ \\
\hline Harga Pokok Produksi (Rp) & $1.013,00$ & 913,80 \\
Margin (13\%) & 131,82 & 118,79 \\
Harga Pokok Penjualan (Rp) & $1.145,81$ & $1.032,59$ \\
Harga Jual Petani (Rp) & $1.456,57$ & $1.570,65$ \\
\hline
\end{tabular}

\section{Harga Pokok Penjualan}

Harga merupakan nilai akhir dari faktor produksi yang digunakan. Penelitian ini dihitung berapa harga ubi kayu yang seharusnya diterima oleh petani dalam menjual hasil produksinya. Perhitungan harga pokok penjualan dilakukan dengan penambahan harga pokok produksi dengan margin keuntungan. Margin keuntungan yang digunakan sebesar 13 persen dengan pertimbangan suku bunga 9 persen dan tingkat inflasi 3,61 persen pada tahun 2017. Tabel 4 menunjukkan bahwa harga pokok penjualan ubi kayu di dua kecamatan berbeda, akan tetapi selisish perbedaan harga pokok penjualan tidak jauh berbeda antara satu sama lain. Harga pokok penjualan ubi kayu di Kecamatan Terusan Nunyai dan harga pokok produksi Rp1.013,99 sedangkan harga jual petani Rp1.456,57 artinya laba yang diperoleh petani sebesar 30,38 persen. Berbeda dengan Kecamatan Bandar Mataram, harga pokok penjualan Rp1.032,59 dengan harga pokok produksi Rp913,80 dan harga jual petani Rp1.570,65, artinya laba yang diperoleh petani sebesar 41,81 persen. Proses penentuan harga ubi kayu sepenuhnya ditentukan oleh pabrik, dengan mengukur kadar pati yang terkandung dalam ubi kayu. Petani selaku produsen ubi kayu, melakukan penjualan ubi kayu dengan cara membayar jasa angkut yang mengantarkan ubi kayu ke pabrik, karena petani tidak memiliki kendaraaan untuk mengangkut hasil panen ke tempat penjualan. Harga jual ubi kayu oleh petani di lokasi penelitian lebih tinggi dibandingkan dengan harga pokok penjualan. Berdasarkan perhitungan harga pokok penjualan berarti bahwa usahatani ubi kayu di dua kecamatan yang lokasinya dekat dengan pabrik maupun jauh dengan pabrik sudah memperoleh keuntungan, karena harga jual yang petani terima di atas perhitungan harga pokok penjualan dengan margin keuntungan 13 persen.

\section{Uji Beda Harga Pokok Penjualan}

Analisis harga pokok penjualan dilakukan uji beda rata-rata parametik independent sample t-test untuk mengetahui apakah terdapat perbedaan harga pokok penjualan usahatani ubi kayu berdasarkan jarak lokasi pabrik. Tabel 5 menunjukkan uji beda harga pokok penjualan berdasarkan lokasi usahatani yang dekat dengan pabrik (Kecamatan Terusan Nunyai) dan yang jauh dari pabrik (Kecamatan Bandar Mataram) memiliki hasil perbedaan yang signifikan dengan sig (2-tailed) sebesar 0,00. Berdasarkan hasil tersebut dapat disimpulkan bahwa nilai sig (2-tailed) $<0,05$ maka tolak $\mathrm{H}_{0}$, artinya terdapat perbedaan yang signifikan antara harga pokok penjualan ubi kayu yang dekat dengan lokasi pabrik dan jauh dari lokasi pabrik. Hal tersebut dikarenakan faktor jarak berpengaruh terhadap biaya pengangkutan yang akan dikeluarkan oleh petani. Biaya angkut yang dikeluarkan Kecamatan Bandar Mataram lebih besar dibandingkan Kecamatan Terusan Nunyai, dimana semakin jauh lokasi usahatani ubi kayu dari pabrik menyebabkan semakin tingginya biaya transportasi yang harus dikeluarkan oleh petani. Pendapatan dan harga pokok produksi petani terdapat perbedaan antara dua lokasi penelitian, dimana perbedaan tersebut dikarenakan jenis bibit yang digunakan, dan biaya tunai yang dikeluarkan petani yaitu biaya pupuk, biaya herbisida, sewa lahan, pajak dan biaya angkut.

\section{Faktor-Faktor Yang Mempengaruhi Produksi Ubi Kayu}

Untuk mengetahui faktor-faktor yang mempengaruhi produksi ubi kayu di Kabupaten Lampung Tengah digunakan pendugaan fungsi produksi berdasarkan analisis linier berganda dengan memasukkan seluruh variabel bebas yang diduga berpengaruh terhadap produksi usahatani ubi kayu.

Tabel 5. Hasil analisis uji beda rata-rata sampel harga pokok produksi, harga pokok penjualan, dan pendapatan berdasarkan lokasi pabrik

\begin{tabular}{|c|c|c|c|c|c|}
\hline \multirow[t]{2}{*}{ Variabel } & \multirow{2}{*}{$\begin{array}{l}\text { Terusan } \\
\text { Nunyai }\end{array}$} & \multirow{2}{*}{$\begin{array}{l}\text { Bandar } \\
\text { Mataram }\end{array}$} & \multicolumn{2}{|c|}{$\begin{array}{c}\text { Lavene's Test for Equality of } \\
\text { Variance }\end{array}$} & \multirow{2}{*}{$\begin{array}{c}\begin{array}{c}\text { t-test for Equality of } \\
\text { Means }\end{array} \\
\text { Sig. (2-tailed) }\end{array}$} \\
\hline & & & $\mathrm{F}$ & $\mathrm{T}$ & \\
\hline Harga Pokok Produksi (Rp/kg) & $1.002,02$ & 838,17 & 5.624 & 7.832 & ,000 \\
\hline Harga Pokok Penjualan (Rp/kg) & $1.132,28$ & 947,14 & 5.624 & 7.832 & 000 \\
\hline Pendapatan Atas Biaya Total (Rp/ha) & $11.063 .129,88$ & 19.721.991,94 & 2.740 & 6.779 &, 000 \\
\hline
\end{tabular}


Model regresi yang digunakan adalah model regresi Ordinary Least Square (OLS) dengan menggunakan program software SPSS (Statistic Package for Social Science) versi 24 dan Eviews 9. Tabel 6 menunjukkan bahwa variabel yang berpengaruh nyata terhadap produksi ubi kayu adalah bibit (X2), pupuk urea (X3) dan dummy lokasi(D). Hasil regresi linier berganda telah dilakukan pengujian terhadap masalah multikolinearitas dan heterokedastisitas, nilai VIF variabel luas lahan, bibit dan tenaga kerja lebih dari 10 artinya model yang digunakan terdapat gangguan multikolinearitas.

Tabel 6. Hasil analisis regresi pendugaan faktor yang mempengaruhi produksi ubi kayu sebelum dilakukan transformasi

\begin{tabular}{llrrr}
\hline Variabel & Koefisien & \multicolumn{1}{c}{ t-hit } & Prob. & \multicolumn{1}{c}{ VIF } \\
\hline Konstanta & 0,198 & 0,053 & 0,958 & \\
Luas Lahan & 0,072 & 0,185 & 0,854 & 336.095 \\
Bibit & $1,047 * * *$ & 2,707 & 0,009 & 337.681 \\
P. Urea & $0,006 *$ & 1.858 & 0,068 & 1.235 \\
P. KCl & 0,001 & 0,396 & 0,693 & 1.553 \\
P. TSP & 0,000 & $-0,044$ & 0,965 & 1.436 \\
P. Phonska & 0,004 & 1,536 & 0,130 & 1.283 \\
P. SP36 & $-0,002$ & $-1,002$ & 0,320 & 1.124 \\
P. Organik & $-0,002$ & $-0,503$ & 0,617 & 1.475 \\
TK & $-0,046$ & $-0,525$ & 0,602 & 21.957 \\
Dummy lokasi & $-0,273 * * *$ & $-4,402$ & 0,000 & 5.860 \\
\hline R-squared & 0,988 & & \\
Adjusted R-squared & 0,977 & & \\
F-statistic & 9,095 & & \\
Prob (F- statistic) & \multicolumn{5}{c}{0,000} & \\
Prob Obs* R-squared & 0,941 & \\
Keterangaan : \\
* Nyata pata taraf kepercayaan 90 persen \\
** Nyata pada taraf kepercayaan 99 persen
\end{tabular}

Tabel 7. Hasil analisis regresi pendugaan faktor yang mempengaruhi produksi ubi kayu setelah dilakukan transformasi

\begin{tabular}{llrrr}
\hline Variabel & Koefisien & \multicolumn{1}{c}{ t-hit } & Prob. & VIF \\
\hline Konstanta & 0,022 & 0,006 & 0,996 & \\
Bibit & $1,022^{* *}$ & 2,459 & 0,017 & 4,762 \\
P. Urea & $0,008^{* *}$ & 2,340 & 0,022 & 1,122 \\
P. KCl & 0,001 & 0,161 & 0,873 & 1,544 \\
P. TSP & $-0,002$ & $-0,737$ & 0,464 & 1,402 \\
P. Phonska & 0,004 & 1,348 & 0,183 & 1,291 \\
P. SP36 & $-0,003$ & $-1,315$ & 0,193 & 1,111 \\
P. Organik & $-0,001$ & $-0,203$ & 0,839 & 1,446 \\
TK & 0,059 & 0,674 & 0,503 & 1,296 \\
Dummylokasi & $-0,238^{* * *}$ & $-3,625$ & 0,001 & 5,676 \\
\hline R-squared & & 0,627 & & \\
Adjusted R-squared & & 0,393 & & \\
F-statistic & & 4,535 & & \\
Prob (F- statistic) & & 0,000 & & \\
Prob Obs* R-squared & 0,964 & & \\
\hline K
\end{tabular}

Keterangaan :

* *Nyata pata taraf kepercayaan 95 persen

*** Nyata pada taraf kepercayaan 99 persen
Model di uji dengan uji white, nilai Prob $O b s * R$ squared diperoleh $(0,941 \geq 0,05)$, artinya model regresi tidak terjadi masalah heterokedastisitas. Untuk menanggulangi masalah multikolinearitas dilakukan tindakan dengan melakukan transformasi variabel. Dalam penelitian ini, variabel luas lahan ditransformasi ke dalam variabel bebas lainnya, maka model regresi baru yang digunakan adalah bibit (X2), pupuk urea (X3), pupuk $\mathrm{KCl}(\mathrm{X} 4)$, pupuk TSP (x5), pupuk phonska (X6), pupuk SP36 (X7), pupuk organik (X8), tenaga kerja (X9), dan dummy lokasi (D).

Tabel 7 menunjukkan bahwa nilai $\mathrm{VIF}<10$, sehingga model regresi tidak terdapat gangguan multikolinearitas. Nilai Prob Obs $R$-squared $(0,964 \geq 0,05)$ artinya bahwa dalam hasil analisis tidak terjadi masalah heterokedastisitas. Variabel bibit, pupuk urea, dan dummy berpengaruh nyata terhadap produksi ubi kayu, sedangkan variabel pupuk $\mathrm{KCl}$, pupuk TSP, pupuk phonska, pupuk SP36, pupuk organik dan tenaga kerja tidak berpengaruh secara nyata terhadap produksi ubi kayu. Bibit berpengaruh nyata terhadap produksi ubi kayu dengan nilai koefisien regresi sebesar 1,022 artinya adalah setiap penambahan bibit ubi kayu sebesar satu persen, maka akan meningkatkan produksi ubi kayu sebesar 1,022 kg.

Penelitian ini sejalan dengan penelitian Anggraini et al. (2016) tentang efisiensi teknis, alokatif dan ekonomi pada usahatani ubi kayu di Kabupaten Lampung Tengah yang menyatakan bahwa produksi ubi kayu dipengaruhi oleh luas lahan, jumlah bibit, pupuk N dan pupuk K. Pupuk urea berpengaruh nyata terhadap produksi ubi kayu dengan nilai koefisien regresi yaitu 0,008 , artinya semakin banyak pupuk urea yang digunakan, maka akan semakin tinggi produksi ubi kayu yang dihasilkan. Hal ini berarti setiap penambahan pupuk urea satu pesen akan meningkatkan produksi sebesar 0,008 persen. Hasil penelitian ini sejalan dengan penelitian milik Fitriana, Zakaria dan Kasymir (2018) tentang analisis efisiensi produksi usahatani ubi kayu di Kecamatan Natar Kabupaten Lampung Selatan, dalam penelitiannya faktor yang mempengaruhi faktor produksi ubi kayu adalah luas lahan, pupuk urea dan tenaga kerja. Variabel dummy berpengaruh nyata terhadap produksi ubi kayu dengan tingkat kepercayaan 99 persen. Nilai Adjusted R-squared untuk petani kelompok sebesar 0,393 atau sebesar $(39,30 \%)$, yang artinya setelah disesuaikan sebesar 39,30 persen variasi total produksi ubi kayu dipengaruhi oleh variabel luas lahan, pupuk urea, pupuk $\mathrm{KCl}$, pupuk TSP, pupuk phonska, pupuk 
SP36, pupuk organik,dan tenaga kerja, sedangkan 60,70 persen sisanya dijelaskan oleh variabel lain yang tidak dimasukkan ke dalam model. Nilai yang didapatkan Prob F-statistic sebesar 0,000 yang berarti bahwa variabel luas lahan, pupuk urea, pupuk $\mathrm{KCl}$, pupuk TSP, pupuk Phonska, pupuk SP36, dan pupuk organik secara bersamasama berpengaruh nyata terhadap produksi ubi kayu dengan tingkat kepercayaan 99 persen.

\section{KESIMPULAN}

Pendapatan usahatani ubi kayu atas biaya total di Kecamatan Terusan Nunyai sebesar Rp11.211.630,63 per hektar dengan harga pokok produksi metode variable costing Rp790,44/kg dan metode full costing Rp1.013,99/kg, sedangkan harga pokok penjualan ubi kayu sebesar Rp1.145,81/kg dan di Kecamatan Bandar Mataram pendapatan atas biaya total Rp17.501.131,19 per hektar dengan harga pokok produksi metode variable costing Rp723,54/kg dan metode full costing Rp913,80/kg, harga pokok penjualan sebesar Rp1.032,59/kg. Harga jual ubi kayu oleh petani lebih besar dibandingkan dengan harga pokok penjualan, berarti usahatani ubi kayu di Kabupaten Lampung Tengah menguntungkan. Terdapat perbedaan yang signifikan antara usahatani ubi kayu yang dekat dengan lokasi pabrik (Kecamatan Terusan Nunyai) dan jauh dari lokasi pabrik (Kecamatan Bandar Mataram). Produksi ubi kayu secara nyata dipengaruhi oleh bibit, pupuk urea dan dummy lokasi, sedangkan pupuk $\mathrm{KCl}$, pupuk TSP, pupuk phonska, pupuk SP36, pupuk organik dan tenaga kerja tidak berpengaruh nyata pada produksi ubi kayu.

\section{DAFTAR PUSTAKA}

Anggraini N, Harianto dan Anggraeni L. 2016. Efisiensi teknis, alokatif dan ekonomi pada usahatani ubi kayu di Kabupaten Lampung Tengah Provinsi Lampung. Jurnal Ilmu Ilmu Agribisnis, $\quad 4(1) \quad$ : $\quad$ 43-56. https://journal.ipb.ac.id/index.php/jagbi/ article/view/15732/11597. [06 Februari 2019].

BPS [Badan Pusat Statistik]. 2016. Statistik Indonesia. http://www.bps.go.id/publicatin /2016/07/04/statistik-indonesia.2016.html pdf [24 Oktober 2017].

BPS [Badan Pusat Statistik] Provinsi Lampung. 2017. Lampung Dalam Angka. http://lampung.bps.go.id/website/pdf_publikas i/Provinsi-Lampung-Dalam-Angka-2016.pdf [25 Oktober 2017].

BRI [Bank Rakyat Indonesia]. 2017. Tingkat Suku Bunga Tahun 2017. Bri.co.id. [24 Oktober 2017].

Fitriana MD, Zakaria WA dan Kasymir E. 2018. Analisis efesiensi produksi usahatani ubi kayu di Kecamatan Natar Kabupaten Lampung Selatan. Jurnal Ilmu Ilmu Agribisnis, 7 (1): 22-27.

http://jurnal.fp.unila.ac.id/index.php/JIA/articl e/view/3327/2548. [5 November 2018].

Gujarati DN. 2003. Ekonometrika Dasar. Diterjemahkan oleh S.Zain. Penerbit Erlangga. Jakarta.

Kuotsoyiannis A. 1982. Modern Microeconomics. Second Edition. The MacMillan Press Ltd.

Mulyadi. 2001. Akutansi Manajemen : Konsep, Manfaat, dan Rekayasa, Edisi Ketiga. Penerbit Salemba Empat. Jakarta.

Mulyadi. 2007. Sistem Akuntansi. Selemba. Jakarta.

Soekartawi. 2003. Teori Ekonomi Produksi dengan Pokok Bahasan Analisis Cobb-Douglas. PT. RajaGrafindo. Jakarta.

Sugiarto, D Siagian, LT Sunaryanto dan Oetomo, DS. 2003. Teknik Sampling. PT Gramedia Pustaka Utama. Jakarta.

Sugiyono. 2007. Metode Penelitian Kuantitatif Kualitatif dan $R \& D$. Alfabeta. Bandung.

Suliyanto. 2011. Ekonometrika Terapan: Teori dan Aplikasi dengan SPSS. Penerbit CV Andi Offest. Yogyakarta. 